ket, on a background of exposure to another similar product, must be weighed against any safety considerations. Systematic efforts are being made by academic researchers, Health Canada and the pharmaceutical industry to better define and address the problems of PRCA.

The importance of reporting adverse reactions to Health Canada or the manufacturer cannot be overstated. Health care practitioners are encouraged to familiarize themselves with the guidelines and mechanisms for adverse reaction reporting (see the Web site of the Canadian Adverse Reaction Monitoring Program, www.hc-sc.gc.ca/hpfb-dgpsa /tpd-dpt/index_adverse_e.html).

\section{Carole Légaré}

Acting Director, Marketed Biologicals

Biotechnology Products Division

Christoper Turner

Director General

Marketed Health Products Directorate

\section{Anges V. Klein}

Manager

Clinical Evaluation Division

Biologics and Genetics Therapies

Directorate

Health Canada

Ottawa, Ont.

\section{Reference}

1. Sibbald B. Eprex warning issued, but no ban. CMA7 2004;170(5):778.

2. Important drug safety information. Eprex (epoetin alfa) sterile solution. Revised prescribing information for patients with chronic renal failure [advisory online]. Ottawa: Health Canada; 2004 Jan 13. Available: www.hc-sc.gc.ca/hpfb-dgpsa/tpd-dpt /eprex3_hpc_e.html (accessed 2004 Jul 7).

3. Casadevaall N, Nataf J, Viron B, Kolta A, Kiladjian JJ, Martin-Dupont P, et al. Pure red-cell aplasia and antierythropoietin antibodies in patients treated with recombinant erythropoietin N Engl 7 Med 2002;346:469-75.

4. Epoetin alfa and pure red cell aplasia. Austr Adverse Drug React Bull [serial online] 2002;21(3). Available: www.tga.health.gov.au/adr/aadrb /aadr0208.htm\#4 (accessed 2004 Apr 26).

DOI:10.1503/cmaj.1041010

\section{Does testosterone affect effect?}

W

hen Luke Fazio and Gerald Brock" write that "Testosterone
... does not effect [sic] reflexogenic or psychogenic erections," do they mean that testosterone does not directly cause (i.e., effect) such erections? Or did they mean to use "affect," to indicate that testosterone does not influence or modify such erections? If, as I suspect, the latter is the case, then the corrected statement, that testosterone does not affect psychogenic erections, is somewhat at odds with a statement earlier in the same paragraph that "androgens play a predominantly modulating role by their effect on libido and sexual behaviour."

Perhaps reference to the cited reference would affect (or even effect) clarity here.

\section{Bill Danby}

Lecturer, Adjunct Staff

Darmouth Medical School

Hanover, NH

\section{Reference}

1. Fazio L, Brock G. Erectile dysfunction: management update. CMAf 2004;170(9):1429-37.

DOI:10.1503/cmaj.1040804

\section{[One of the authors responds:]}

\} \text { Te agree that our description of } $\checkmark$ the impact of testosterone on penile erections ${ }^{1}$ was unclear. The literature supports a modulating role of testosterone on erectile function. ${ }^{2}$ This hormone clearly increases responsiveness to phosphodiesterase type 5 inhibitors, and testosterone levels correlate with measured frequency of sleep erections. However, testosterone levels do not directly correlate with erectile function, and supplementing low levels of testosterone in hypogonadal men or administering exogenous testosterone to eugonadal men generally does not enhance erectile performance.

\section{Gerald Brock}

Division of Urology

Faculty of Medicine and Dentistry

University of Western Ontario

London, Ont.

\section{References}

1. Fazio L, Brock G. Erectile dysfunction: management update. CMAf 2004;170(9):1429-37.

2. Shabsigh R. Hypogonadism and erectile dysfunction: the role for testosterone therapy. Int 7 Impot Res 2003;15(Suppl 4):S9-13.

DOI:10.1503/cmaj.091544

\section{Corrections}

7 he report on the subcutaneous use of Eprex ${ }^{1}$ contained 3 errors. The most serious appeared in the first sentence of paragraph 2: in fact, Health Canada advised against subcutaneous injection of the drug, not intravenous as printed. The second error was use of the term "HSA-3" to describe the drug formulation containing polysorbate-80; the correct term is "HSA-free." Finally, pure red cell aplasia is not always irreversible, as was stated in the article.

\section{Reference}

1. Sibbald B. Eprex warning issued, but no ban. CMAJ 2004;170(5):778.

DOI:10.1503/cmaj.1041338

n article about Germany's new user A fees ${ }^{1}$ should have stated that the price was 10 Euros (about Cdn\$16.50).

\section{Reference}

1. Orellana C. Germany's new user fee cuts doctor visits. CMA7 2004;171(3):226.

DOI:10.1503/cmaj.1041330 